IRA-International Journal of Management \& Social Sciences

ISSN 2455-2267; Vol.07, Issue 03 (2017)

Pg. no. 502-508

Institute of Research Advances

http://research-advances.org/index.php/RAJMSS

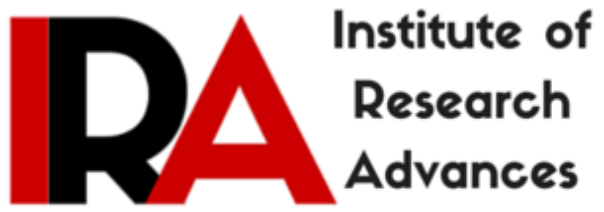

\title{
Constitutional Perspectives of Gender Based Discrimination in J\&K State: A Critical Analysis
}

\section{Saroop Kumar}

Ph.D Research Scholar (SRF), P.G. Department of Law

University of Jammu, Jammu (J\&K) 180006, India.

Type of Review: Peer Reviewed.

DOI: http://dx.doi.org/10.21013/jmss.v7.n3.p11

\section{How to cite this paper:}

Kumar, S. (2017). Constitutional Perspectives of Gender Based Discrimination in J\&K State: A Critical Analysis. IRA-International Journal of Management \& Social Sciences (ISSN 2455-

2267), 7(3), 502-508. doi:http://dx.doi.org/10.21013/jmss.v7.n3.p11

(C) Institute of Research Advances

\section{(c) EY-NC}

This work is licensed under a Creative Commons Attribution-Non Commercial 4.0

International License subject to proper citation to the publication source of the work.

Disclaimer: The scholarly papers as reviewed and published by the Institute of Research Advances (IRA) are the views and opinions of their respective authors and are not the views or opinions of the IRA. The IRA disclaims of any harm or loss caused due to the published content to any party. 


\section{ABSTRACT}

The constitution of India is the supreme law of the country which prohibits any kind of discrimination based on sex, religion or race etc. and any such law shall not be operative after the commencement of the constitution which authorizes such discrimination in any part of the country whereas the state of $J \& K$ which is also one of the federal units of the Indian Federation enjoys some special status under article 370 of the constitution and in this manuscript the authors have tried to point out the gender based discrimination in the state of $J \& K$ especially right to immovable property and its constitutionality with historical perspective of all such provisions which protect such discriminatory practice in the state side by side the justification in favour as well as against for such exception legal position in the state and other issue to be covered in this endeavour the role played by the judiciary to mitigate the grievances of the women section of the state with its post effects in terms of their property rights or status of permanent resident with all incidents etc. in the state in case they enter into matrimonial tie with non-resident of the state.

Keywords: Constitution, Federation, Discrimination, Statutory Provisions and Judicial view

\section{Introduction:}

The state of $\mathrm{J} \& \mathrm{~K}$ is one of the twenty-nine federal units of the Indian federation ensured some special status under the constitution of India ${ }^{1}$ and federal relations between union of India and state of $J \& K$ purely work on federal principle.

Federalism is one of the basic features of the Indian constitution and express provisions incorporated in the constitution of India ${ }^{2}$. The term federation is derived from the Latin word "Foedus" which means a treaty or an agreement ${ }^{3}$. It speaks about the existence of the pre-existing federal units to constitute a federation. The expression 'federalism' is the latest stage in the evolution of man to understand one another and learn to live together by accommodating another's view point without forgiving or compromising one's own goal in a peaceful and orderly manner. The distribution of powers between federal government at national level and local government (provincial/state/federal units) ensures that the representatives of the population have the capacity to make law within their own jurisdiction assigned to them ${ }^{4}$.

Interestingly state of $\mathrm{J} \& \mathrm{~K}$ is only state which negotiated with union of India with regards to sharing of power in the envisaged federal framework and reasons for such reservations were like implementation of New Kashmir and other one was uncertainty prevailing in the state at the time of execution of Instrument of accession. The concessions so acceded to the state by union of India as per Delhi agreement of 1952 were later on incorporated in the constitution of $\mathrm{J} \& \mathrm{~K}$ and further constitution order was issued by president of India in 1954 for the extension other constitution provisions to the state including part third which deals with fundamental rights.

It is pertinent to mention here that in order to protect certain laws enforceable in the state from the operation of the constitutional especially under article 13 , a new article 35-A was added by the above said president order which is applicable only to the state of $\mathrm{J} \& \mathrm{~K}$.

\footnotetext{
${ }^{1}$ Article 370, constitution of India

${ }^{2}$ Id. Part XI \&XIIth

${ }^{3}$ K.L.Bhatia, Federalism and Friction in Centre-State Relations -A Comparative Review of Indian and German Constitution: New Delhi (2001) p.2

${ }^{4}$ Ibid. p. 4
} 
The division of power is the essence of the federal principle secured by constitutional provisions in India. The perusal of the constitutional provisions reveal that state of $\mathrm{J} \& \mathrm{~K}$ has wide legislative as well as financial power vis-a vis parliament has been restricted to those subjects which were accessed by Instrument of Accession or later on assigned by the state government. There are eight parts of the constitution still don't apply in J\&K and moreover there is no state list for the state. Thus, the above said exceptions provide some special status to the state.

\section{Fundamental rights and their application in the state}

The fundament rights were extend to the state of $\mathrm{J} \& \mathrm{~K}$ in 1954 by president order with some exceptions and modification so that their operation will not hurdles to implement some reformative programmes initiated by the state government like land reforms ${ }^{5}$ and other one was to ensure for their local residents (state subjects) jobs security etc. hence the issue of state subject and their regulations got shielded from the wrath of equality provisions of the Indian constitution.

In this way all those changes which were incorporated by amendment especially relating to the fundamental rights still awaiting their application to the state as all such amendments has not been extended to the state as per article 370,depriving the permanent residents from all such fundamental rights e.g. reservation issues in governments services. Moreover the right to property is still a fundamental right in the state ${ }^{6}$ and the constitutional position is clear on interpretation of section ${ }^{7}$ when read with article 370 .

\section{Women and their rights in the state of J\&K: Critical view}

The state of Jammu and Kashmir has its own constitution ${ }^{8}$ wherein part- III titled as PERMANENT RESIDENTS $^{9}$ incorporates detailed provisions pertaining to the permanent residents ${ }^{10}$ of the state. The state legislature is empowered to make law defining the classes of persons who are or shall be permanent residents of the state, special provision for bill relating to the permanent residents and fundamental rights guaranteed to them under the Constitution of India. To explain it more clearly section 6 of the J\&K Constitution says who the permanent residents of the state are given as under:

1. Every person who is, or is deemed to be, a citizen of India under the provisions of the constitution of India shall be a permanent resident of the state, if on 14.05.1954

a) He was a state subject of class- I or class -II or

b) Having lawfully acquired immovable property in the state or has been an ordinarily resident in the state for not less than ten years prior to that date.

2. Any person who before 14.05.1954 was a state subject of class Ior II and who having migrated after 1.3.1947 to territory now included in Pakistan, returns to the state under a permit for resettlement in the state or for permanent return issued by or under the authority of any law made by the state legislature shall on such return be a permanent resident of the state.

3. In the instant section, expression state subject of class Ior II shall have the same meaning as in the state notification No.I-L/84, dated 20.04.1927 ${ }^{11}$, read with state notification No.13-L/1989 dated 27.06.1932.

\footnotetext{
${ }^{5}$ The Big landed (estates abolition) Act,1950

${ }^{6}$ Constitution(44thAmendment)Act,1978 is not applicable in the state

${ }^{7}$ Section 10 ,constitution of J\&K

${ }^{8}$ The constitution of J\&K, 1957

9 Ibid.Sections 6-10

${ }^{10}$ Before 1952 the local residents of the J\&K state were known as state subjects.

${ }^{11}$ Issued during the regime of Maharaja Hari Singh with the aim to protect the interest of local residents in the matter of government jobs or property rights or other privileges
} 
At present there is only one category of state subject known as permanent resident of the state ${ }^{12}$ thus all erstwhile distinction among different classes like class- I, or class-III is abolished.

This section authorizes state legislatures to make law to define who is or shall be permanent residents and for such bill should be passed by not less than $2 / 3$ rd majority of the total membership of the house ${ }^{13}$. The permanent residents of the state shall have all those fundamental rights guaranteed to them under the Constitution of India ${ }^{14}$. The fundamental rights under Part-III of the Indian Constitution are not applicable to the state directly.

The rights and privileges to which permanent residents of the state are entitled but not available to the outsiders within the territory of the state are discussed under.

I. Employment under the state government services

II. Acquisition of immovable property in the state

III. Settlement in the state

IV. Right to scholarships and such other forms of aid as the state government may provide.

The state legislatures under article 35-A of the Indian Constitution empowers to make special laws for the benefit of the permanent residents in the above mentioned matters and such law shall not be void on the ground that it is inconsistent with or takes away or abridges any rights conferred on the other citizens of India under part-III of the Constitution .

Now, the question arises as to how these provisions discriminate on the basis of gender issue in the state is discussed as under

The woman of the state who married outside the state and man who brings an outsider women to the state before 2002, the legal position was, that on married to non- resident of the state women used to lose all rights available to them in the state, but high court of the state opined while disposing number of petitions challenging this discrimination against the women of the state that those women who married to outsider will not lose their right like employment in government sectors ,their property rights in the state but the important question emerges whether on return to state, children born to them out of wedlock with non-permanent resident of the state will acquire any right on immovable property as hereditary rights in the state is still pending their disposal before division bench of J\&K high court ${ }^{15}$. On the other hand an outsider woman on married to a male who is permanent resident can became permanent resident with all rights and privileges in the state. This gender based discrimination in the state can be seen in the form that whether a child is born to male(brother) or female(sister). The child of male(brother) in the state will become permanent resident with all rights whereas a child born to female(sister) who married outside the state will not entitled to the status of permanent resident even though decedents of female(daughter/sister) live in the state permanently. In simple words we can say that children of brother and sister (son or daughter) in the state J\&K may not be of the same status in the matter of property rights etc.

In this context full bench(three judges) of $\mathrm{J} \& \mathrm{~K}$ high court at Jammu in the case of state of $J \& K v D r$. Susheela Sawhney in the year 2002 while adjudicating on a reference made to it by single judge bench " whether on married to non-permanent resident of the state the permanent resident women of the state will lose the status of permanent resident with all rights and privileges in the state" the majority judgment by Justice .V.K. Jhanji answered the reference negatively that on married to out-sider (nonresident) a women of the state will not lose his right over property and employment in government services etc. advocate general, advocate M.A.Goni pleaded the interpretation laid in the Note -III

\footnotetext{
${ }^{12}$ Op.cit Ref.8,Section 7

${ }^{13}$ Id. Section 9

${ }^{14}$ Id. Section 10

${ }^{15}$ Prabhjit Kour v State of J\&K
} 
appended to the notification of the 1927 an official notification which provides that wife or widow of a state subject of any class shall acquire the status of her husband as state subject of the same class as her husband, so long as she resides in the state and does not leave the state for permanent residence outside the state. It was argued that the above mentioned note is not applicable to women/female who is permanent residents of the state as they will not lose the status of permanent resident with all rights and privileges in the state as long as they remain the citizen of India ${ }^{16}$. Justice Doabia said that this note-III is applicable to those wives who are outsider (non-permanent resident and married to a permanent resident of the state)

The state government led by People Democratic Party filed a Special Leave Petition in the Supreme Court in the year of 2003 to get this popular judgment reviewed by the apex court but being apprehensions of a reverse judgment against their Special Leave Petition (SLP) they decided to withdraw the same.

\section{Legislative measures to perpetuate sex based discrimination in the state}

Further, as the Kashmir based politics was not ready to accept the high court decision against local laws of the state perpetuating the grass discrimination between a male and female resident of the state. The ruling party PDP proposed to present an infamous bill in the state legislative assembly ${ }^{17}$ to disqualify the women permanent resident of the state on their marriage to an outsider (non-permanent resident) to the status of being permanent resident with all other consequences, but fortunately due to lack of sufficient number in the upper house the proposed bill could not be passed to become statutory law to legalize the discriminate on gender base in the state. As per state's constitution this proposed law relating to permanent resident must be passed by not less than two-third majority of the total membership of the respective house.

Another such efforts was made to project the Kashmiri identity against women's rights especially when the rest of the world was observing the International Women's Day on 8th of March, 2010 a process for disempowering women was being initiated in Jammu \& Kashmir assembly in the form of a legislative bill $^{18}$ to debar the weaker section of the society in the state from certain right exclusively based on their sex which cannot be maintainable in rest of India except J\&K. no doubt it was a private member bill with an aim to provide such provisions that a woman who marries outside the state would lose her status of permanent resident (PR) thereby disentitled to hold immovable property, or to secure state government services including political right to case vote or to contest elections for the legislative assembly of the state also.

In this endeavour while introducing the discriminatory bill in the legislative assembly Mr. Murtaza Khan of the People's Democratic Party (PDP), a regional party in the state was of view that a female permanent resident acquires the status of her husband as such a women ceases to be permanent resident on marrying someone who is not a permanent resident of the state. However the bill later on was dropped, not because of the unacceptable position in constitutional perspective it embodying for women but on technical ground that is, when a bill sought a constitutional amendment could not be introduced in the upper house of the state assembly ${ }^{19}$.

\footnotetext{
${ }^{16}$ AIR J\&K 83(96)

${ }^{17}$ J\&K Resident(Disqualification) Bill,2004

${ }^{18}$ J\&K Permanent Residents (Disqualification) Bill, 2010

${ }^{19}$ The J \&K State has Bicameral Legislative assembly
} 
Now the legal position in the state regarding married women of the state who opted to marriage with an out-sider is that, they can enjoy the status of permanent resident with all civil and political rights in the state. $^{20}$

But it is pertinent to mention here that if by reason of divorce or death of her husband a married women forced to live in the state with their decedents (children) born out of wedlock with non- resident then she can enjoy those rights but after her death their decedents would not be entitled to property of their mother in the state of J\&K. That property will go to women's parental relative or in absence of any such relatives, to the state government.

The further the other aspect of discrimination based on gender even after the landmark verdict of the state high court regarding the issuance of permanent resident certificate in favour of the female/ daughter/women which used to be endorsed as "VALID ONLY TILL MARRIAGE" ${ }^{21 "}$ this rule was challenged before high court through public interest litigation ${ }^{22}$ in which high court issued an interim direction to state government not to use such an endorsement on the permanent resident certificate issued in favour of women. In the year of 2010 PDP M.L.A introduced the earlier lapsed bill as private bill regarding J\&K Permanent Resident (Disqualification) in the upper house which was termed as non-existent by Deputy Chairman under section 147 of J\&K Constitution. As this bill pertains to the amendment in the part third of the state Constitution which is required to be first present in the lower house of the state legislative assembly.

The above discussed gender based discrimination in the state of $J \& K$ up to some extent is due to much provisions under article 370 , because it due to this provision no law passed by the Indian parliament shall be applicable in the state of $\mathrm{J} \& \mathrm{~K}$.

The fundamental rights in the part -IIIof Indian Constitution are not applicable in this part of Indian territory and section 10 of the $J \& K$ Constitution is enabling provision in this context. Some modifications and exceptions have been effected by the presidential order under article 370 to extend part -III of Indian constitution in the state e.g. article 16(3) is not applicable in the state as a result the interdistrict employment is barred in the state of $J \& K$ under $J \& K$ any such provision in any other part of the country is unconstitutional as only parliament has power under article 16(3) to pass such law. The fundamental right to property still exist as fundamental right in the state of J\&K. ${ }^{23}$ For the implementation of various fundamental rights article $35^{24}$ extended in modified form in J\&K which now enables the state legislature to make law regarding permanent resident, employment in government services, to acquire immovable property of to get scholarship benefit and any such law shall not be void under part-III. As result of this provision such draconian laws in the state are constitutionally valid.

\section{Conclusion and suggestions:}

That state of $J \& K$ is one of the federal units of the Indian federation endowed with special rights to regulate the status of their permanent residents, but based on historical perspective it seems not so relevant as today no such protection required to protect the local resident from outsiders in case of jobs opportunities in the state. The judiciary has played vital role to mitigate the grievances of the women sections up to some extent to unsettled the precedent being followed in the state and now politicians has to do rest to bring this weaker section at par with other citizens of the country with regards their rights. The fundamental rights applied here in this state in modified form so such discriminatory laws are also valid in the state.

\footnotetext{
${ }^{20}$ Prof. S.K.Sharma,The Constitution of J\&K (2011) p. 103

${ }^{21}$ Government CircularNo.-RevL-B87/74 of Jan.2005

${ }^{22}$ Hari Om v State of J\&K 2005

${ }^{23}$ Op.cit.Ref.6

${ }^{24}$ Article 35-A of Indian Constitution titled as saving of laws with respect to permanent residents and other rights
} 
Now there is dire need to relook the prevailing gender based discrimination in the state of the J\&K in current scenario because the rationales applied by the King of the state long before seems no relevancy today as the residents of the state are also able to compete at national level for any jobs and such example are there like SHAW FAZAL topped in UPSC conducted exams for prestigious all India services. Moreover an outsider woman after marriage here can acquire such status then why not the children of a women who by chance has to live in this state after marriage with an outsiders. 